\title{
GENOTYPIC DIFFERENCES IN ROOT SYSTEM SIZE IN WHITE MUSTARD IN RELATION TO BIOMASS YIELD AND SOIL NITROGEN CONTENT
}

\author{
Martin Hajzler ${ }^{1}$, Jana Klimešová ${ }^{1}$, Petra Procházková ${ }^{1}$, Tomáš Středa ${ }^{1}$ \\ ${ }^{1}$ Department of Crop Science, Breeding and Plant Medicine, Faculty of AgriSciences, Mendel University in Brno, \\ Zemědělská 1, 61300 Brno, Czech Republic
}

\begin{abstract}
HAJZLER MARTIN, KLIMEŠOVÁ JANA, PROCHÁZKOVÁ PETRA, STŘEDA TOMÁŠ. 2018. Genotypic Differences in Root System Size in White Mustard in Relation to Biomass Yield and Soil Nitrogen Content. Acta Universitatis Agriculturae et Silviculturae Mendelianae Brunensis, 66(4): 871-881.

Growing catch crops is one of the possible strategies to decrease erosion and nitrogen loss from soil profiles. Biomass yield and root system size have significant impacts on the soil nitrogen content. a three-year field experiment with eight varieties of white mustard (Sinapis alba L.) was established to evaluate the effects of genotype and environment on biomass yield, soil nitrogen content and rooting parameters. Significant effects of genotype were found for root length density (RLD), root surface density (RSD) and specific root length (SRL) in the plow layer $(0-20 \mathrm{~cm}$ ) and for root system size (RSS), measured by electrical capacitance method, during three phenological phases. Higher biomass yield in varieties with higher RLD and RSD values during ripening and a larger RSS during flowering were found in dry conditions. Relationship of the root system and biomass yield to nitrate and ammonia nitrogen content varied in different environments. We found a significant relation between the RSS and ammonia nitrogen content in more fertile environment on average over the three years. The nitrate nitrogen content was related to the RLD, RSD and SRL in favorable year at shallow soil depths $(0-20 \mathrm{~cm})$.
\end{abstract}

Keywords: catch crop, drought, root length density, root biomass, Sinapis alba, soil nitrogen

\section{INTRODUCTION}

A high crop yield demand leads to an increase in the amount of applied fertilizers. Since nitrogen is one of the most dynamic and mobile elements, its management is difficult and so could represent a significant loss primarily in the form of nitrate leaching (Delgado, 2002). Catch crops are one of the instruments used to eliminate water erosion (Bodner et al., 2010) and nitrogen loss from soil profiles (Kristensen and Thorup-Kristensen, 2004; Francis et al., 1998). The catch crop's ability to take up nitrogen is dependent on the seeding time, nitrogen availability in the soil, precipitation distribution (Aronsson et al., 2016; Francis et al., 1998; Vos and van der Putten, 1997) and plant morphological and physiological parameters. Catch crop shoot biomass and root systems must be sufficient sinks for uptake adequate amount of nutrients (Thorup-Kristensen 2001; Bodner et al., 2010). Another aspect of successful growing of catch crops is fast shoot biomass development to ensure allocation of nitrogen before it leaches from the soil (Francis et al., 1998). Catch crops are mainly sown in the summer months; thus, it is desirable for the plant to have vigorous and deep roots able to absorb water from the deeper soil layers, enabling fast plant emergence and growth during drought conditions. The rooting depth may be also important for nitrogen uptake (Meisinger et al., 1991). Brassicaceae species 
develop denser root systems in deeper soil layers than cereals and can therefore absorb nutrient resources more effectively (Thorup-Kristensen, 2001). Mustard, the most commonly grown catch crop in Central Europe, shows the fastest growth of shoots compared to the other species commonly used as catch crops (phacelia, rye, vetch) (Bodner et al., 2010). In the study by Wendling et al., (2016), among 20 catch crop species, mustard was one of the crops with the largest and fastest production of shoot biomass, weight and surface area of roots. The ability of white mustard to mitigate nitrogen leaching was confirmed by Thomsen and Hansen (2014). Considering the abovementioned findings, biomass yield along with qualitative and quantitative root system parameters in relation to water and nutrient consumption may have significant impacts on catch crop effectiveness. The interspecific variation of yield and root characteristics of catch crops was confirmed (Francis et al., 1998; Bodner et al., 2010; Wendling et al., 2016). At present, research has not addressed the intraspecies differences of catch crops, specifically white mustard. Genotype differences in root system parameters could contribute to the optimal choice of varieties with more efficient soil nitrogen uptake and improved tolerance to unfavorable environmental conditions.

The aims of this paper were to evaluate the effects of environment and genotype of white mustard catch crop on (i) the root parameters and the root system size (RSS) in different phenological phases, (ii) biomass yield, and (iii) soil nitrogen content after the harvest, and (iv) to describe the relationships among these traits.

\section{MATERIALS AND METHODS}

\section{Plant material and field conditions}

The trial was established in three years 2010-2012 at two localities - Třešňovec $\left(49.945195^{\circ} \mathrm{N}\right.$, $\left.16.598374^{\circ} \mathrm{E}\right)$ and Troubsko $\left(49.171596^{\circ} \mathrm{N}\right.$, $\left.16.505863^{\circ} \mathrm{E}\right)$ in the Czech Republic. Třešňovec lies in a submontane area at an altitude of 415 meters above sea level. The annual average of air temperature is $7.36^{\circ} \mathrm{C}$ and the annual rainfall total is $735.7 \mathrm{~mm}$. This location is characterized by an inferior soil fertility. The soil type is a modal pseudogley with a topsoil layer (Ap) of $0-30 \mathrm{~cm}$ with a subsequent marbled horizon Bm.

The Troubsko locality, located at an altitude of 300 meters above sea level, is characterized by more fertile soils in a warmer and mostly drier area. The annual average of air temperature is $8.7^{\circ} \mathrm{C}$ and the annual rainfall total is $490.6 \mathrm{~mm}$. The soil type is a gleyic fluvisol with a topsoil layer (Ap) of 0-18 cm and horizon $\mathrm{M}$ up to the depth of $70 \mathrm{~cm}$. Pedological characteristics of soils in experimental localities are shown in Tab. I.

Fig. 1 shows the weather course at Třešňovec and Troubsko-average daily air temperature and monthly precipitation totals compared to the standard long-term climatological mean (1961-1990) for mustard vegetation periods as a main crop in Czech Republic. Precipitation and air temperature conditions of the months were assessed on the basis of Recommendation of World Meteorological Organization to describing meteorological or climatological conditions (Kožnarová and Klabzuba, 2002). Volumetric soil moisture (\%) was monitored by automatic electromagnetic sensors VIRRIB (AMET, Velké Bílovice, Czech Republic) in 15-minute intervals. Sensors were placed in the soil depth of $20 \mathrm{~cm}$ and $40 \mathrm{~cm}$.

The soil profile was sufficiently saturated with water in 2010. Soil moisture did not decline under $60 \%$ of available water holding capacity (AWHC) (wet year) at both locations in May. The soil moisture at both locations fluctuated between the wilting point (in depth of $20 \mathrm{~cm}$ ) and $40 \%$ of AWHC (40 cm) in May and June in 2011, but the comparison of the monthly precipitation totals with the standard long-term climatological mean shows the water conditions were normal in these months (except for the month of June in Troubsko) (Fig. 1). The wilting point in the upper soil layer $(20 \mathrm{~cm}$ ) was reached in May in 2012 (dry year). The availability of water at deeper soil layer $(40 \mathrm{~cm})$ was reduced substantially below the $40 \%$ of AWHC from the third decade of May to the end of the growing season (27\% of AWHC in Troubsko, $19 \%$ of AWHC in Třešňovec). Differences between monthly precipitation totals and the standard long-term mean characterize the months of May and June as dry (except for the month of June in Třešňovec).

I: Physical pedological characteristics (\%) of soils in experimental localities Troubsko and Třešňovec in soil depth of $10 \mathrm{~cm}$ and $38 \mathrm{~cm}$.

\begin{tabular}{lcccc}
\hline \multicolumn{1}{c}{ Locality } & \multicolumn{2}{c}{ Troubsko } & \multicolumn{2}{c}{ Třešňovec } \\
\hline Soil depth & $10 \mathrm{~cm}$ & $38 \mathrm{~cm}$ & $10 \mathrm{~cm}$ & $38 \mathrm{~cm}$ \\
Water retention capacity & 32.3 & 29.2 & 29.6 & 29.8 \\
Maximum capillary water capacity according to Novák & 39.2 & 38.0 & 37.2 & 36.3 \\
Field water capacity & 41.3 & 42.0 & 41.7 & 39.0 \\
Porosity & 45.0 & 44.1 & 48.2 & 42.7 \\
Wilting point & 14.9 & 17.2 & 14.5 & 15.5 \\
\hline
\end{tabular}




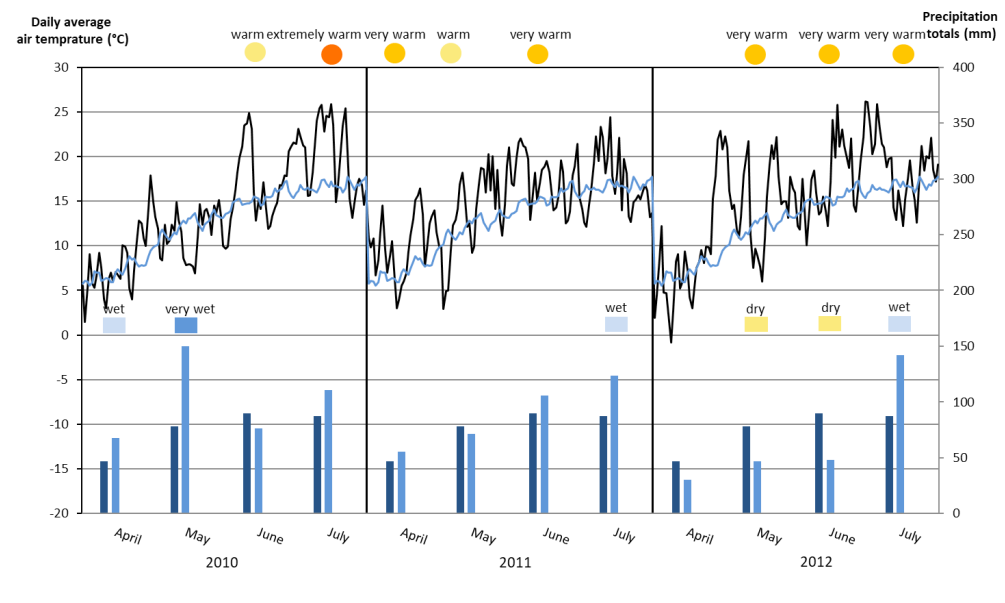

TŘEŠŇOVEC

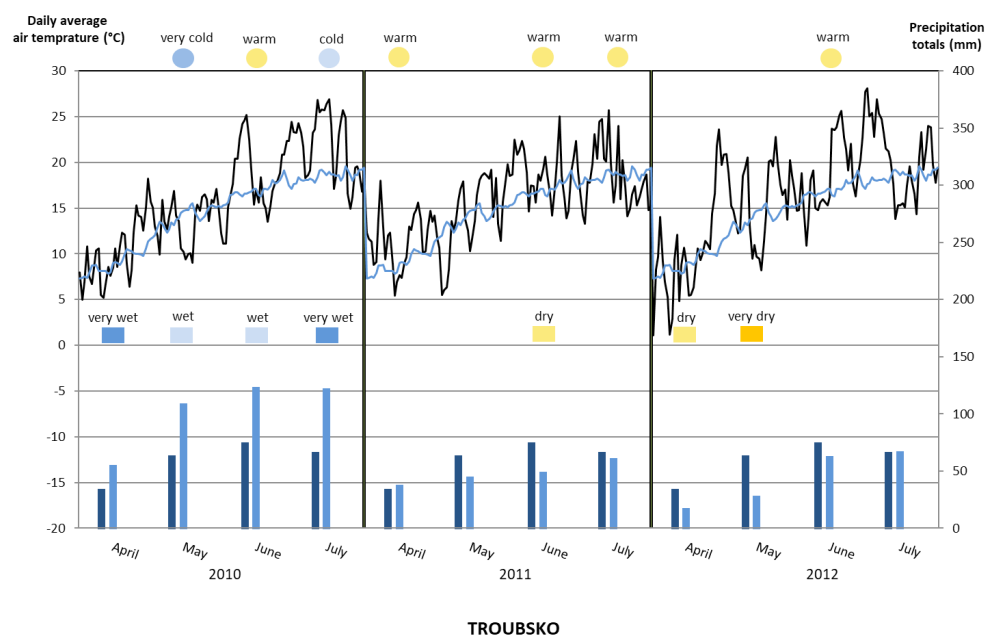

1: Average daily air temperature (black line), long-term standard climatological mean of air temperature (blue line), precipitation totals (light blue column), long-term standard climatological mean of precipitation (dark blue column) in the Tŕešñovec and Troubsko localities during the vegetation period of white mustard (April-July) for three years. Deviations of values of meteorological variables air temperature and monthly precipitation from standard long-term climatological mean (colored symbols) were evaluated according to Kožnarová and Klabzuba (2002)

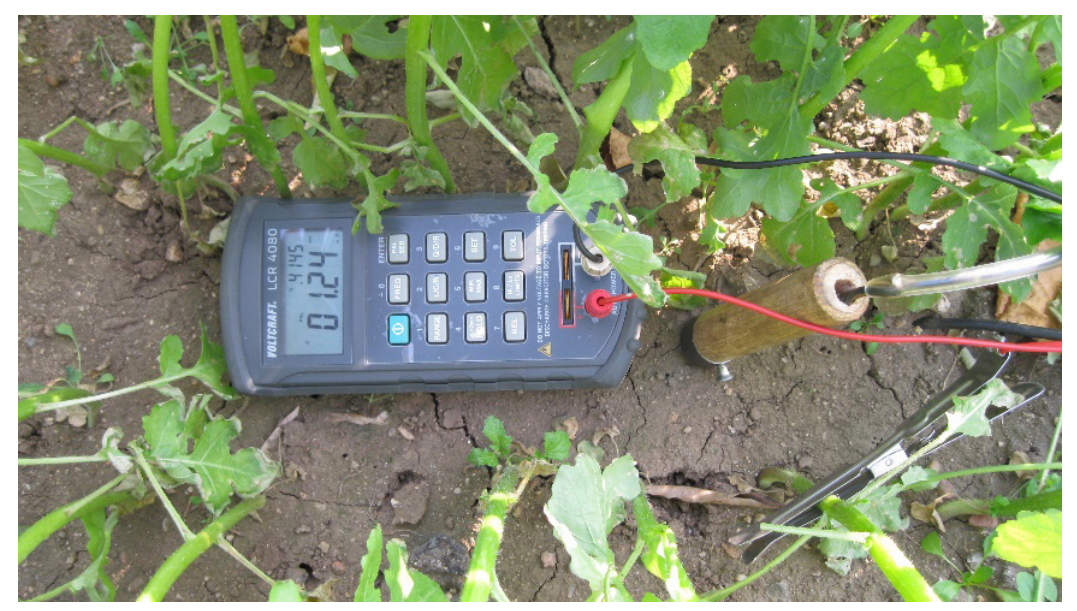

2: Non-destructive measurement of the root system of mustard plants in the stem elongation phase using an LCR device connected to two electrodes - needle (placed in the soil) and clamp (placed on plant base) 
Eight varieties of white mustard (Sinapis alba L.), Medicus, Seco, Semper, Sirte, Sito, Severka, Veronika and Zlata, were grown with a seed rate of $8 \mathrm{~kg} \mathrm{ha}^{-1}$ in experimental plots with an area of $10 \mathrm{~m}^{2}$, in four replicates. The vegetation was established in April according to standard seed producing technology. The presowing fertilization in Troubsko consisted of $23 \mathrm{~kg}$ of $\mathrm{P}, 50 \mathrm{~kg}$ of $\mathrm{K}$, and $39 \mathrm{~kg}$ of N; in Třešňovec, it consisted of $14 \mathrm{~kg}$ of $\mathrm{P}, 27 \mathrm{~kg}$ of $\mathrm{K}$ and $32 \mathrm{~kg}$ of $\mathrm{N}$ per hectare. Different doses of fertilizers reflect the rather intensive farming practice in Troubsko and the more extensive farming practice in marginal agricultural regions such as Třešňovec. The shoot biomass was harvested during the full ripe stage (BBCH 80-89) from the $1 \mathrm{~m}^{2}$ plots. The biomass was weighed after drying at $60^{\circ} \mathrm{C}$ to a constant weight. Soil samples from the $0-20 \mathrm{~cm}$ soil layer were collected from each plot during the harvest. The concentration (mg kg-1 of soil) of nitrogen nitrate $-\mathrm{N}^{-1} \mathrm{NO}_{3^{-}}$and ammonia nitrogen $-\mathrm{N}_{-} \mathrm{NH}_{4}{ }^{+}$was assessed by the ion selective electrode MPH 181 (Monokrystaly, Přepeře, Czech Republic).

\section{Root system size measurements}

During the vegetation (elongation phase- $\mathrm{BBCH}$ 30-39, flowering-BBCH 60-65 and ripening-BBCH 70-75), the root system size (RSS) of 10 plants in each variety in 4 replications was evaluated by the electrical capacitance measurement method in nanofarads (nF) (Chloupek, 1972). This non-destructive method for evaluating root systems in situ uses a VOLTCRAFT LCR 4080 device (CONRAD, Hirschau, Germany) (Fig. 2). This method is only suitable for the relative assessment of the root systems of equally aged plants growing in the same soil conditions.

\section{Measurements of root parameters}

The root systems were also evaluated using a reference destructive soil core method in BBCH 70. Cylinder samples of the soil and the root system in the row were taken with a $6.3 \mathrm{~cm}$ diameter probe in the $0-60 \mathrm{~cm}$ and 0-40 $\mathrm{cm}$ (only in the wet year) soil layers, cut into the $10 \mathrm{~cm}$ long cylinders and washed in a system of sieves with mesh perimeter of 1.6 and $0.6 \mathrm{~mm}$. Manually collected roots were scanned and analyzed in WinRhizo software (Régent Instruments Inc., Québec, Canada). Root mass samples were dried to a constant weight at $103{ }^{\circ} \mathrm{C}$, and the root weight (RW) of each cylinder sample was determined. Index values of root length density (RLD) (length of roots $\left(\mathrm{cm} \mathrm{cm}^{-3}\right.$ of soil), root surface density (RSD) (surface area of roots $\left(\mathrm{cm}^{2} \mathrm{~cm}^{-3}\right.$ of soil) and specific root length-SRL ( $\mathrm{m} \mathrm{g}^{-1}$ of roots) were calculated.

\section{Data analysis}

Correlation analysis $(\mathrm{n}=8)$ and analysis of variance (ANOVA) were used and tested by the Tukey's honest significant difference (HSD) test using Statistica, version 12 (StatSoft Inc., Tulsa, OK, USA). Evaluated varieties were divided into four

II: The effect of the experimental factors and their interactions (\%) on root system size (RSS) value variability and average RSS ( $n F$ ) over three years for eight mustard varieties in three growth stages (stem elongation, flowering, ripening). Statistically significant values at $p \leq 0.05$ are marked by an asterisk. Different letters indicate statistically significant different values at $p \leq 0.05$.

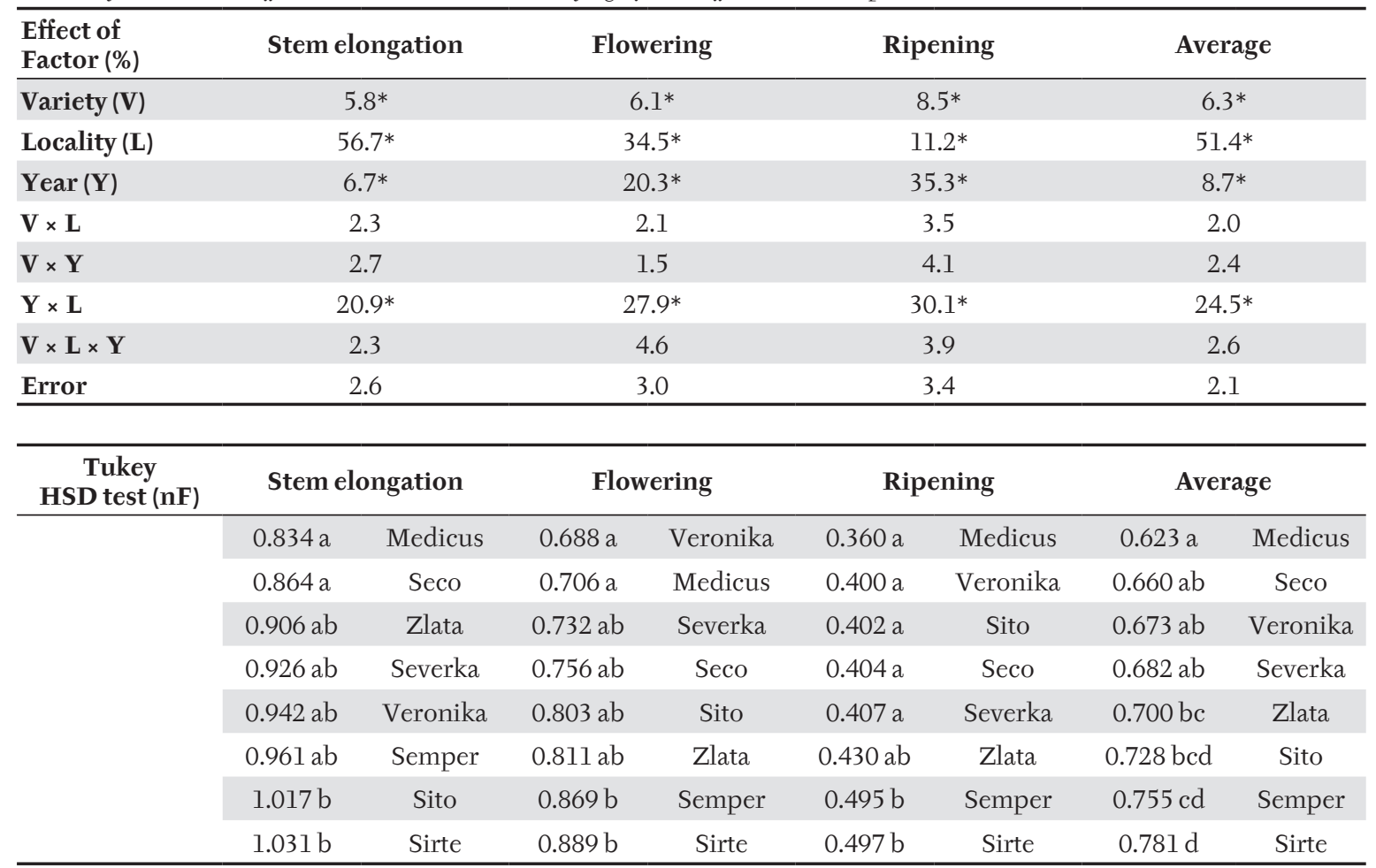


groups based on the rooting parameters according to results of principal component analysis (PCA)(data not shown): Medicus and Veronika (MV), Seco and Severka (SSe); Semper and Sirte (SSi); Sito and Zlata (SZ). The groups were analyzed by ANOVA for traits as follows: biomass yield, soil nitrate nitrogen and ammonia nitrogen content in the $0-20 \mathrm{~cm}$ soil layer and root system parameters (RLD, RSD, SRL, RW) in the $0-20 \mathrm{~cm}$ and the $20-40 \mathrm{~cm}$ soil layers. The root system size values were evaluated by ANOVA and HSD test for each variety separately $(n=8)$.

\section{RESULTS}

\section{Biomass yield}

The three-year average of dry biomass yield reached $6.98 \mathrm{t} \mathrm{ha}^{-1}$. The highest yield (10.25 $\mathrm{t} \mathrm{ha}^{-1}$ ) occurred at both localities during the year 2011. During 2010, the wet year, the yield was lower by $20.6 \%$. The drought during the spring months (April-June) in 2012 (Fig. 1) caused a significantly lower yield (by $70.6 \%$ ) at both localities than that in 2011. The three-year average of the biomass yield at Troubsko was $25 \%$ higher than that at Třešňovec. The effect of year (43.1\%), locality (19.4\%) and interaction of year and locality (24.7\%) were statistically significant $(\mathrm{p} \leq 0.05)$. Genotype differences in biomass yield were not confirmed (3.1\%).

\section{Root system size and rooting parameters}

The statistically significant effects of year, locality, variety, and the interaction between locality and year on RSS values were confirmed. Rapid biomass (aerial biomass and root system) growth was primarily influenced by the experimental locality (The effect of the factor of locality in stem elongation phase $56.7 \%$ ), but the maintenance of vigorous root systems until the generative phase could be influenced by weather conditions (increased effect of year up to the ripening phase $35.3 \%$ ) (Tab. II).

The root system size was affected by year and locality, but the emphasis was placed on the intervarietal differences of RSS (Tab. II). The effect of variety increased with the length of the vegetation period, reaching up to $8.5 \%$ in the ripening stage. Most varieties produced a similarly large root system (in relative comparison among varieties), even though the weather and water supply were different each year (wet year 2010 compared with dry year 2012). We have found varieties that had larger root systems during all three growth stages (Semper, Sirte) (Tab. II). These varieties had by $13 \%$ in average and during ripening, by $24 \%$ larger root systems compared to the three-year average of all other varieties. This contrasts with the Sito variety, in which the RSS values decreased with age. Medicus had a stable and small root system.

The values of root parameters (RLD, RSD, SRL, RW) were significantly influenced by the year and locality (Tab. III). The RLD and RSD values declined with increasing soil depth. The largest proportion of root biomass was found in the top layer from 0 to $20 \mathrm{~cm}(60-70 \%$ of the roots). Low RLD, RSD, SRL and RW values in the year 2010 were caused by the humid character of the weather with abundant precipitation (for RLD, see Fig. 3). With increasing dryness of the year, the ratio of roots in the top layers decreased to the benefit of the roots in the deeper part of the soil, and at the same time, the SRL value increased. Třešňovec (the less fertile locality) showed higher RLD, RSD, SRL values than Troubsko in all years. The effect of genotype on RLD, RSD and SRL was confirmed in the $0-20 \mathrm{~cm}$ soil layer (Tab. III) and for RLD in the $0-60 \mathrm{~cm}$ soil layer (data not shown). Significantly higher values were found for the Sito and Zlata varieties compared to the Seco and Severka varieties. However, in deeper soil layers, the effect of the year decreased, while the effect of the genotype (up to $11.4 \%$ ) and the interaction of the genotype with the environment (year $\times$ locality) (up to $21.4 \%$ ) on RLD and RSD increased. The fineness of the roots increased with increasing soil depth and with improved soil water conditions. The highest SRL values in the $0-20 \mathrm{~cm}$ soil layer $\left(103.3 \mathrm{~m} . \mathrm{g}^{-1}\right)$ were

III: The effect of experimental factors (\%) on the values of rooting parameters in two soil layers (0-20 and 20-40 cm). Values marked with an double asterisk and asterisk, resp. are statistically significant at $p \leq 0.01$ and $p \leq 0.05$, respectively

\begin{tabular}{lcccccccc}
\hline \multicolumn{1}{c}{$\begin{array}{c}\text { Rooting } \\
\text { parameters }\end{array}$} & \multicolumn{2}{c}{ RLD } & \multicolumn{2}{c}{ RSD } & \multicolumn{2}{c}{ SRL } & \multicolumn{2}{c}{ RW } \\
\hline Soil depth (cm) & $0-20$ & $20-40$ & $0-20$ & $20-40$ & $0-20$ & $20-40$ & $0-20$ & $20-40$ \\
\hline Year (Y) & $23.9^{* *}$ & $34.0^{* *}$ & $24.1^{* *}$ & $33.9^{* *}$ & $14.2^{* *}$ & 17.4 & $18.5^{*}$ & $21.4^{*}$ \\
$\mathbf{L o c a l i t y}(\mathbf{L})$ & $31.8^{* *}$ & 9.7 & $27.4^{* *}$ & 5.6 & $32.8^{* *}$ & 10.4 & $20.4^{* *}$ & 10.4 \\
\hline $\mathbf{V a r i e t y}(\mathbf{V})$ & $6.6^{*}$ & 7.2 & $7.8^{*}$ & 8.3 & $10.5^{* *}$ & 15.3 & 13.1 & 11.8 \\
$\mathbf{Y} \times \mathbf{L}$ & $14.7^{* *}$ & $15.6^{* *}$ & $16.5^{* *}$ & $16.6^{* *}$ & $14.1^{* *}$ & 5.6 & $16.6^{*}$ & $16.1^{*}$ \\
$\mathbf{Y} \times \mathbf{V}$ & $5.1^{*}$ & 5.3 & 5.1 & 5.2 & $7.6^{*}$ & 11.8 & 5.0 & 9.9 \\
$\mathbf{L} \times \mathbf{V}$ & $9.3^{* *}$ & 6.5 & $9.0^{* *}$ & 7.3 & $9.2^{*}$ & 11.2 & 11.4 & 9.0 \\
$\mathbf{Y} \times \mathbf{L} \times \mathbf{V}$ & $5.5^{*}$ & $15.4^{* *}$ & $6.4^{*}$ & $16.9^{* *}$ & 6.8 & $18.5^{*}$ & 7.2 & 12.2 \\
$\mathbf{E r r o r}$ & 3.1 & 6.3 & 3.6 & 6.4 & 4.7 & 9.8 & 7.8 & 9.3 \\
\hline
\end{tabular}


found during the humid year 2010, while the lowest values $\left(47.0 \mathrm{~m} \mathrm{~g} \mathrm{~g}^{-1}\right)$ were found during the dry year 2012. With the decrease of available water in the soil, the mustard roots become shorter, heavier and thicker. A statistically significant effect of variety (10.5\%) was found for SRL at a depth of $0-20 \mathrm{~cm}$, where the Medicus and Veronika varieties had finer root systems (higher values of SRL) than the Semper, Sito, Seco and Severka varieties.

\section{Root system size and rooting parameters in relation to biomass yield}

The ability of varieties to provide satisfactory yields were not always related to larger root systems. The relationship of root system size and shoot biomass production could be determined by the interaction of the genotype and the environment. These interactions could cause weak relationships during favorable water conditions (2010 and partly in 2011). In contrast, in the dry year, the higher biomass yield of varieties at the Třešnovec locality was connected with a greater RSS in the flowering phase $\left(r=0.840^{*}, y=1.3466 x-0.4948, R^{2}=0.706\right)$. In the dry year 2012 at Troubsko, a significant relationship between biomass yield and RSD in the ripening phase was discovered in the $0-20 \mathrm{~cm}$ $\left(\mathrm{r}=0.742 *, \quad \mathrm{y}=0.6274 \mathrm{x}+0.1126, \quad \mathrm{R}^{2}=0.551\right)$ and $20-40 \mathrm{~cm}\left(\mathrm{r}=0.708^{*}, \mathrm{y}=0.7279 \mathrm{x}+0.147\right.$, $\mathrm{R}^{2}=0.501$ ) soil layers. At this locality, when drought decreased the yield significantly (by $70.6 \%$ in comparison with the year 2011), higher RLD and RSD values in the whole soil profile $(0-60 \mathrm{~cm})$ were related to higher biomass yield $\left(\mathrm{r}=0.790 *, \mathrm{y}=0.0243 \mathrm{x}+0.1181, \quad \mathrm{R}^{2}=0.625\right.$; $\left.\mathrm{r}=0.888^{* *}, \mathrm{y}=1.2706 \mathrm{x}+0.0908, \mathrm{R}^{2}=0.789\right) . \mathrm{SRL}$ and RW were not correlated with biomass yield.

\section{Soil nitrogen content}

The nitrogen content was significantly affected by the year, the locality and the interaction between year and locality $(21.3 \%, 37.9 \%$ and $22.5 \%$, respectively). The effect of genotype on the $\mathrm{N}^{-\mathrm{NO}_{3}}{ }^{-}$ content was considerably low (1.8\%), while a higher but insignificant effect of genotype was found for the $\mathrm{N}-\mathrm{NH}_{4}{ }^{+}$content (6\%). The statistically
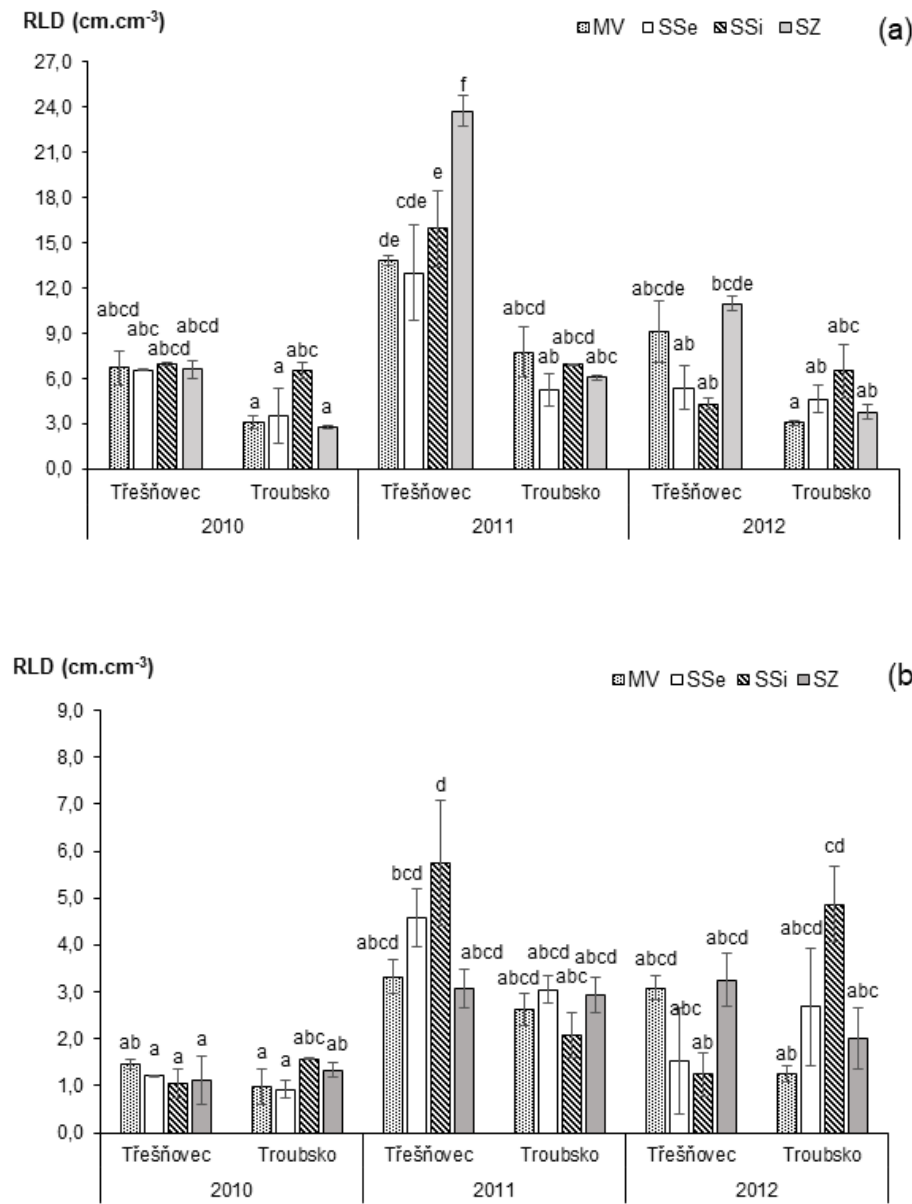

3: Means of root length density (RLD) ( $\left.\mathrm{cm} \mathrm{cm}^{-3}\right)$ in the $0-20 \mathrm{~cm}$ (a) and 20-40 $\mathrm{cm}$ (b) soil layers from two localities over three years for the 4 groups of varieties (MV, SSe, SSi, SZ). Different letters indicate statistically significant differences between pairs at $p \leq 0.05$. Error bars represent $\pm S E$ 
significant genotype differences in nitrate nitrogen content were observed only for the wet year 2010 in Troubsko, where the highest biomass yield of all varieties and simultaneously highest soil nitrate nitrogen content was found. The lowest biomass yield was observed in the Sito and Zlata varieties, which showed significantly higher $\mathrm{N}-\mathrm{NO}_{3}{ }^{-}$contents (Fig. 4) and the lowest RLD and RSD values in the $0-20 \mathrm{~cm}$ soil layer (Fig. 3).
Observed relationships between the RSS, the root parameters and the soil nitrogen content were either not evident or negative in almost all environments. The RSS was correlated with the $\mathrm{N}-\mathrm{NH}_{4}{ }^{+}$content of the soil after the harvest in Troubsko during the stem elongation phase $\left(\mathrm{r}=-0.720^{*}\right)$ and during all vegetation periods in the wet year 2010 and when all three years were considered together $\left(\mathrm{r}=-0.807 * / \mathrm{r}=-0.718^{*}\right)$ (Fig. 5). In the year 2011
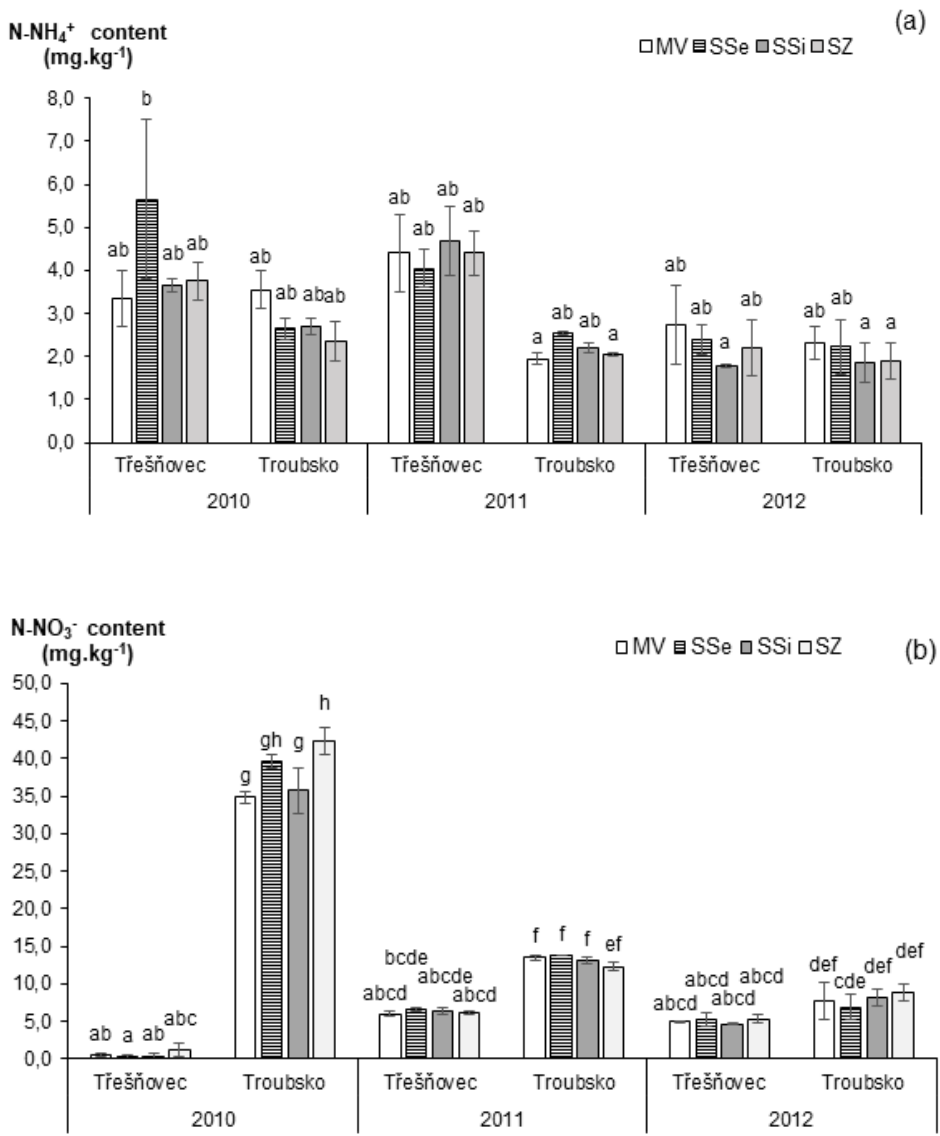

4: Means of ammonia nitrogen (a) and nitrate nitrogen (b) content in the soil $\left(\mathrm{mg} \mathrm{kg}^{-1}\right)$ after the harvest at two localities over three years for four groups of varieties (MV, SSe, SSi, SZ). Different letters indicate statistically significant differences between pairs at $p \leq 0.05$. Error bars represent $\pm S E$
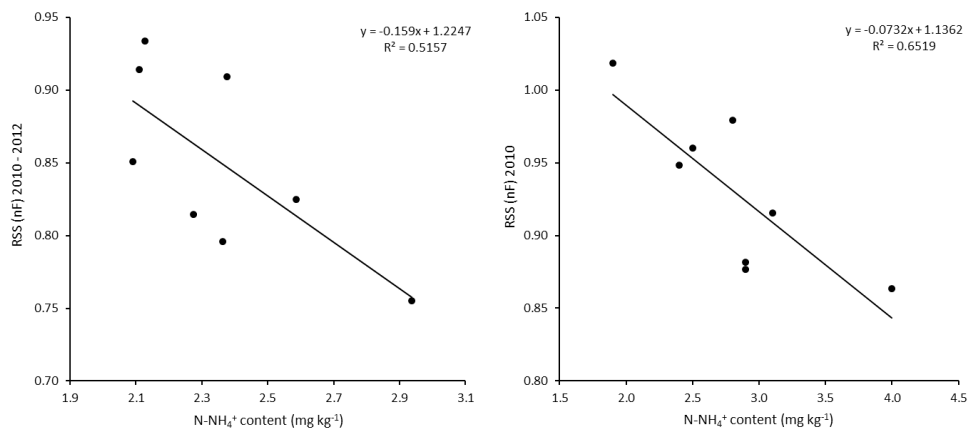

5: The relationship of ammonia nitrogen content $\left(\mathrm{N}-\mathrm{NH}_{4}+, \mathrm{mg} \mathrm{kg}^{-1}\right)$ and $\mathrm{RSS}(\mathrm{nF})$ in average for all growth stages in 2010 - 2012 and in average for all growth stages in 2010 in Troubsko. 
at both localities, less nitrate nitrogen was left by the plants, with higher RLD, RSD and SRL values in the shallow soil layer $(0-20 \mathrm{~cm})(\mathrm{r}=-0.837 * *$, $\mathrm{y}=-0.131 \mathrm{x}+11.215, \quad \mathrm{R}^{2}=0.700 ; \quad \mathrm{r}=-0.827 *$, $\mathrm{y}=-6.4519 x+11.242, \quad \mathrm{R}^{2}=0.684 ; \quad \mathrm{r}=-0.710^{*}$, $y=-0.0178 x+10.776, R^{2}=0.505$, respectively).

\section{DISCUSSION}

Root system size was primarily influenced by the experimental locality (decreased effect of locality with the length of vegetation; $56.7 \%$ in elongation phase). Maintaining vigorous root systems until the generative phase was more influenced by weather conditions (increased effect of year up to $35.3 \%$ in ripening stage) than other experimental factors and was significantly regulated by the mustard genotype (8.5\%). A similar effect of genotype on RSS (3-16\%) resp. (7.4-12.4\%) was observed by Chloupek et al. (2006) and Chloupek et al. (2010) in barley, in which the root system was evaluated by the electrical capacitance. We have found varieties which had greater roots during all three terms (Semper, Sirte), which is an effect of selection in breeding, even if not a planned one. Herrera et al. (2010) noted the importance of the fast growth of the roots in deep soil layers at the beginning of vegetation, which may lower nitrogen losses by leaching. Similarly, Kaye and Quemada (2017) suggest growing of a rapid autumn-growing species of cover crops as the most effective crops for reducing $\mathrm{N}$ losses, especially in years, when drought reduced cash crop production and $\mathrm{N}$ uptake. Rapid emergence and vigorous early growth in a wide range of environmental conditions was suggested by Foley (1999) as important breeding objectives for cover crops. Assessment of mustard early root growth in the stem elongation phase in six environments was performed in our experiment using the electrical capacitance measurement. Application of the electrical capacitance measurement method for screening wheat genotypes in field conditions was also suggested by Nakhforoosh et al. (2014) and Postic and Doussan (2016).

Root system parameters of mustard varieties measured with the soil-core method responded to the conditions of the environment. High RLD values were always detected at the more humid and less fertile locality of Třešňovec, where also higher values of the SRL were recorded. Similarly, Elazab et al. (2016) documented an increase in wheat SRL in low nitrogen conditions and discovered higher SRL values at a depth of $0-60 \mathrm{~cm}$ in favorable moisture conditions, while Bowsher et al. (2016) observed only a weak correlation between SRL values and the $\mathrm{N}$ content in the soil and stated that higher SRL values are natural for species originating from high rainfall areas. We have also found higher SRL values in mustard in the years with favorable moisture conditions. On the contrary, low values $\left(23-70 \mathrm{~m} \mathrm{~g}^{-1}\right)$ in the soil layer $0-20 \mathrm{~cm}$ indicate a drought stress in dry year. Short, thickened and hairless roots are typical for cruciferous plants in drought stress (Farooq et al., 2009). Furthermore, under dry conditions, a change in the distribution of the length and surface area of the root system of mustard in the soil profile was observed, while the ratio of roots in the top layers decreased to the benefit of the roots in the deeper part of the soil. Similar behavior of the mustard root system was also observed by Bodner et al. (2010).

The root system size of mustard was not related to biomass yield in two water favorable years. The development of a large root system could be counterproductive when water supplies in the soil are sufficient. Himmelbauer et al. (2013) stated that in cases with favorable moisture conditions, water consumption is more dependent on soil and weather conditions in a locality than on the root distribution in soil. High RSS values, thus, could cause lower yield. Středa et al. (2009) discovered a negative relationship between the grain yield of rapeseed and its RSS in a year with favorable moisture conditions. On the contrary, in the dry year the biomass yield at the Třešňovec locality was significantly affected by RSS in flowering phase. A culmination of activity and growth of the root system occurs during the flowering and subsequently decreases as ripening seeds become the main sink of the assimilates. Cseresnyés et al. (2016) observed an increase of soybean RSS until the beginning of flowering. Wang et al. (2014) showed maximum values of root system weight in wheat during the flowering stage and discovered a significant relationship between RW and grain yield. Higher RSS values during the flowering and ripening stages positively affected the yield and seed count of mustard grown in a pot experiment (Chloupek 1976). High rooting density is an important aspect of effective water consumption by the root system, mainly during drought stress periods (Blum 2011; Nakhforoosh et al., 2014), but the RLD increase should occur primarily in deeper soil layers (Blum 2011) where more soil water supplies are located. To achieve good yields in dry conditions, sustained transpiration is always essential (Blum 2011) and can only be achieved by contact of the root system with a sufficient supply of soil water. Nakhforoosh et al. (2014) observed higher RLD in wheat in deeper soil layers in a year with more limited moisture conditions. Bodner et al. (2007) discovered 14\% more catch crop roots in the $20-60 \mathrm{~cm}$ layer during drought periods in comparison to a year rich in precipitation. In the dry year, we observed an $11.6 \%$ increase in RLD for mustard at the depth of 20-60 cm compared to the year with favorable water conditions. Connections between larger root systems in varieties of barley and higher grain yield under drought conditions was shown in the studies by Chloupek et al. (2010) and Svačina et al. (2014). It is therefore apparent that higher values of rooting parameters and the RSS are beneficial for mustard 
yield under drought conditions. The potential for rapid growth of a large root system could therefore be an advantage for mustard as a late-summer catch crop sown in the dry summer months with limited rainfall.

In one of the three experimental years we found a significant relationship of the rooting parameters and the nitrate content in shallow soil layer. In that year (2011), when the water conditions were favorable, the highest rooting values of all varieties were detected on both locations in the shallow soil layer $0-20 \mathrm{~cm}$ (Fig. 3). Our results imply that the conditions were favorable for mustard to quickly develop shoot biomass along with fine and dense root system. This root system effectively absorbed the nitrate nitrogen present in the shallow soil layer. Fast growth of the root system of the field crops is vital to prevent nitrates from leaching to deeper layers of the soil profile, but the role of the root system in nitrogen uptake efficiency is still controversial (Palta and Watt, 2009). Thorup-Kristensen (2001) discovered that root density to the soil profile depth of $0.5 \mathrm{~m}$ was not correlated with the ability of catch crops to take up nitrate nitrogen. A stronger correlation was found for root system parameters in the 0.5-1 m layer, where Brassicaceae catch crops in particular showed higher root density than cereals. Thorup-Kristensen and Rasmussen (2015) observed similar results, when the relationship between root system growth and nitrogen uptake of catch crops was found in soil profile layers lower than $1 \mathrm{~m}$. However, higher root density did not always lead to an increase in $\mathrm{N}$ consumption (Wendling et al., 2016; Feng et al., 2016; Herrera et al., 2010). When comparing old and modern wheat varieties, Aziz et al. (2016) discovered that the RLD and total length of the root system decreased with ongoing breeding processes, but the efficiency of $\mathrm{N}$ uptake increased.

The ambiguous relationship of the RSS and the nitrogen level in the upper soil layer may also be caused by different nitrate and ammonia nitrogen mobility and the unclear relationship between the quantitative parameters of the root system and the shoot biomass and nitrogen uptake. This was proved in the work of Wendling et al. (2016), which showed that the biomass production and root system density of 20 species of catch crops had no clear effect on the $\mathrm{N}$ uptake efficiency. In our results, intervarietal differences in $\mathrm{N}_{-} \mathrm{NO}_{3}$ - were observed in the soil where nitrate concentration was very high (35-42 $\mathrm{mg} \mathrm{kg}^{-1}$ ) (Troubsko, wet year 2010). This is supported by the results of the study by Herrera et al. (2010), which found that the greatest effect of catch crops planting occurs during wet years and periods of high nitrogen uptake. Therefore, we assume that these environmental conditions were suitable for better detection of possible genotype differences.

\section{CONCLUSION}

The suitability of catch crops for growing is determined by fast biomass growth and efficient nitrogen uptake associated with root system parameters. In eight mustard varieties, a significant effect of genotype was found for root system parameters in the plow layer $(0-20 \mathrm{~cm})$ and for RSS. A large varietal effect on the RSS, which did not change substantially with environmental conditions, suggests the possibility of controlling the RSS by selection. Higher biomass yield in varieties with higher rooting density (RLD, RSD) and larger RSS was found in the dry year. Hence, robust root system could be beneficial for mustard biomass yield under drought conditions. A significant relation was found between the RSS and the ammonia nitrogen content in the soil in the more fertile environment averaged over the three years $\left(\mathrm{r}=-0.718^{*}\right)$, although larger RSS and higher values of rooting parameters of white mustard were associated with lower soil nitrate nitrogen content only in favorable weather conditions in 2011.

Acknowledgment

This work was supported by project QJ1510098 of the National Agency for Agricultural Research and by the project IP 1/2017 of the Internal Grant Agency IGA of Mendel University in Brno.

\section{REFERENCES}

ARONSSON, H., HANSEN, E. M., THOMSEN, I. K., LIU, J., ØGAARD, A. F., KÄNKÄNEN, H. and ULÉN, B. 2016. The ability of cover crops to reduce nitrogen and phosphorus losses from arable land in southern Scandinavia and Finland. Journal of Soil and Water Conservation 71(1): 41-55.

AZIZ, M. M., PALTA, J. A., SIDDIQUE, K. H. M. and SADRAS, V. O. 2016. Five decades of selection for yield reduced root length density and increased nitrogen uptake per unit root length in Australian wheat varieties. Plant and Soil, 413: 181-192.

BLUM, A. 2011. Plant Breeding for Water-Limited Environments. New York: Springer.

BODNER, G., HIMMELBAUER, M., LOISKANDL, W. and KAUL, H. P. 2010. Improved evaluation of cover crop species by growth and root factors. Agronomy for Sustainable Development, 30(2): 455-464.

BODNER, G., LOISKANDL, W. and KAUL, H. P. 2007. Cover crop evapotranspiration under semi-arid conditions using FAO dual crop coefficient method with water stress compensation. Agricultural water management, 93: 85-98. 
BOWSHER, A. W., MASON, C. M., GOOLSBY, E. W. and DONOVAN, L. A. 2016. Fine root tradeoffs between nitrogen concentration and xylem vessel traits preclude unified whole-plant resource strategies in Helianthus. Ecology and Evolution, 6(4): 1016-1031.

CHLOUPEK, O. 1972. The relationship between electric capacitance and some other parameters of plant roots. Biologia Plantarum, 14(3): 227-230.

CHLOUPEK, O. 1976. Evaluation of root system of mustard plants based on dielectric properties and with respect to final yield. [in German: Die Bewertung des Wurzelsystems von Senfpflanzen auf Grund der dielektrischen Eigenschaften und mit Rücksicht auf den Endertrag]. Biologia Plantarum, 18(1): 44-49.

CHLOUPEK, O., FORSTER, B. P. and THOMAS, W. T. 2006. The effect of semi-dwarf genes on root system size in field-grown barley. Theoretical and Applied Genetics, 112(5): 779-786.

CHLOUPEK, O., DOSTÁL, V., STŘEDA, T., PSOTA, V. and DVOŘÁČKOVÁ, O. 2010. Drought tolerance of barley varieties in relation to their root system size. Plant Breeding, 129(6): 630-636.

CSERESNYÉS, I., RAJKAI, K. and TAKÁCS, T. 2016. Indirect monitoring of root activity in soybean cultivars under contrasting moisture regimes by measuring electrical capacitance. Acta Physiologiae Plantarum, 38(5): 121.

DELGADO, J. A. 2002. Quantifying the loss mechanisms of nitrogen. Journal of Soil and Water Conservation, 57(6): 389-398.

ELAZAB, A., SERRET, M. D. and ARAUS, J. L. 2016. Interactive effect of water and nitrogen regimes on plant growth, root traits and water status of old and modern durum wheat genotypes. Planta, 244(1): 125-144.

FAROOQ, M., WAHID, A., KOBAYASHI, N., FUJITA, D. and BASRA, S. M. A. 2009. Plant drought stress: effects, mechanisms and management. Agronomy for Sustainable Development, 29(1): 185-212.

FENG, G., ZHANG, Y., CHEN, Y., LI, Q., CHEN, F., GAO, Q. and MI, G. 2016. Effects of nitrogen application on root length and grain yield of rain-fed maize under different soil types. Agronomy Journal, 108: 1-10.

FOLEY, M. 1999. Genetic approach to the development of cover crops for weed management. Journal of Crop Production, 4(2): 77-93.

FRANCIS, G. S., BARTLEY, K. M. and TABLEY, F. J. 1998. The effect of winter cover crop management on nitrate leaching losses and crop growth. Journal of Agricultural Science, 131(3): 299-308.

HERRERA, J. M., FEIL, B., STAMP, P. and LIEDGENS, M. 2010. Root growth and nitrate-nitrogen leaching of catch crops following spring wheat. Journal of Environmental Quality, 39(3): 845-854.

HIMMELBAUER, M. L., MAJERCKA, J., RODNY, M., NOVÁK, V. and LOISKANDL, W. 2013. The impact of root data details on modelling of soil water transport in soil-plant-atmosphere system. Acta Hydrologica Slovaca, 14:21-31.

KAYE, J. P. and QUEMADA, M. 2017. Using cover crops to mitigate and adapt to climate change. A review. Agronomy for Sustainable Development, 37: 4.

KOŽNAROVÁ, V. and KLABZUBA, J. 2002. Recommendation of World Meteorological Organization to describing meteorological or climatological conditions. Rostlinná výroba, 48(4): 190-192.

KRISTENSEN, H. L. and THORUP-KRISTENSEN, K. 2004. Root growth and nitrate uptake of three different catch crops in deep soil layers. Soil Science Society of America Journal, 68: 529-537.

MEISINGER, J. J., HARGROVE, W. L., MIKKELSEN, R. L., WILLIAMS, J. R. and BENSON, V. W. 1991. Effects of cover crops on groundwater quality. In: HARGROVE, W. L. (Ed.). Cover crops for clean water. Ankeny: Soil and Water Conservation Society, pp. 57-68.

NAKHFOROOSH, A., GRAUSGRUBER, H., KAUL, H. P. and BODNER, G. 2014. Wheat root diversity and root functional characterization. Plant and Soil, 380: 211-229.

PALTA, J. and WATT, M. 2009. Vigorous crop root systems: Form and function for improving the capture of water and nutrients. In: SADRAS, V. and CALDERINI, D. (Eds.). Crop Physiology, Applications for Genetic Improvement and Agronomy. Burlington: Academic Press, pp. 309-325.

POSTIC, F. and DOUSSAN, C. 2016. Benchmarking electrical methods for rapid estimation of root biomass. Plant Methods, 12: 33.

STŘEDA, T., DOSTÁL, V. and ULLMANNOVÁ, K. 2009. Root system as a factor of oilseed rape yield formation, In: MendelNet'09 Agro - Proceedings of International Ph.D. Students Conference. Mendel University in Brno, 25. November. Brno: Faculty of AgriSciences, Mendel University in Brno, pp.141-146.

SVAČINA, P., STŘEDA, T. and CHLOUPEK, O. 2014. Uncommon selection by root system size increases barley yield. Agronomy for Sustainable Development, 34:545-551.

THOMSEN, I. K. and HANSEN, E. M. 2014. Cover crop growth and impact on N leaching as affected by pre- and postharvest sowing and time of incorporation. Soil Use and Management, 30(1): 48-57.

THORUP-KRISTENSEN, K. 2001. Are differences in root growth of nitrogen catch crops important for their ability to reduce soil nitrate-N content, and how can this be measured? Plant and Soil, 230(2): 185-195.

THORUP-KRISTENSEN, K. and RASMUSSEN, C. R. 2015. Identifying new deep-rooted plant species suitable as undersown nitrogen catch crops. Journal of Soil and Water Conservation, 70(6): 399-409.

VOS, J. and VAN DER PUTTEN, P. E. L. 1997. Field observations on nitrogen catch crops. I. Potential and actual growth and nitrogen accumulation in relation to sowing date and crop species. Plant and Soil, 195(2): 299-309. 
WANG, CH., LIU, W., LI, Q., MA, D., LU, H., FENG, W., XIE, X., ZHU, Y. and GUO, T. 2014. Effects of different irrigation and nitrogen regimes on root growth and its correlation with above-ground plant parts in highyielding wheat under field conditions. Field Crops Research, 16: 138-149.

WENDLING, M., BÜCHI, L., AMOSSÉ, C., SINAJ, S., WALTER, A. and CHARLES, R. 2016. Influence of root and leaf traits on the uptake of nutrients in cover crops. Plant and Soil, 409(1-2): 419-434.

Martin Hajzler: xhajzle0@node.mendelu.cz

Jana Klimešová: jana.klimesova@mendelu.cz Petra Procházková:xprocha2@node.mendelu.cz

Tomáš Středa: tomas.streda@mendelu.cz 